\section{B A Institute of \\ YK Business Administration \\ 六下 \\ Karachi \\ Leadership and Ideas for Tomorrow}

Business Review

Volume 7 Issue 2 July-December 2012

7-1-2012

\title{
Gender, behavioral finance and the investment decision
}

\author{
Bimal Jaiswal \\ University of Lucknow, Lucknow, Uttar Pradesh, India \\ Naela Kamil \\ Academy of Higher Learning, Lucknow, Uttar Pradesh, India
}

Follow this and additional works at: https://ir.iba.edu.pk/businessreview

Part of the Corporate Finance Commons, and the Finance and Financial Management Commons

(c) (i)

This work is licensed under a Creative Commons Attribution 4.0 International License.

\section{Recommended Citation}

Jaiswal, B., \& Kamil, N. (2012). Gender, behavioral finance and the investment decision. Business Review, 7(2), 8-22. Retrieved from https://doi.org/10.54784/1990-6587.1201

This article is brought to you by iRepository for open access under the Creative Commons Attribution 4.0 License and is available at https://ir.iba.edu.pk/businessreview/vol7/iss2/2. For more information, please contact irepository@iba.edu.pk. 


\title{
ARTICLE
}

\section{Gender, Behavioral Finance and the Investment Decision}

\author{
Bimal Jaiswal \\ University of Lucknow, Lucknow, Uttar Pradesh, India \\ Naela Kamil \\ Academy of Higher Learning, Lucknow, Uttar Pradesh, India
}

\begin{abstract}
As per classical economic theory, humans are completely rational decision makers who carefully evaluate all facts and evidences before taking decisions that aim at maximizing outcomes. However it has been found that in real life humans are not totally rational, rather they are influenced by various behavioural factors while making decisions. Behavioural Finance has thus emerged as an emerging field that studies the influence of psychology on financial decisions.

However, it still remains to be investigated whether the impact of behavioural factors is homogenous on all individuals or whether the demographic and psychographic characteristics of the individuals in any way influence the behavioural investment decision.

This research takes up one demographic variable, gender, and attempts to investigate the extent to which gender differences influence behavioural investment decisions.
\end{abstract}

Keywords: Behavioural Finance, Herd Behaviour, Mental Accounting, Over-reaction, Prospect Theory.

\section{Introduction}

As per classical economic theory, humans are completely rational decision makers who carefully evaluate all facts and evidences before taking decisions that aim at maximizing outcomes. However it has been found that in real life humans are not totally rational, rather they are influenced by various behavioural factors while making decisions. Behavioural Finance has thus emerged as an emerging field that studies the influence of psychology on financial decisions.

However, it still remains to be investigated whether the impact of behavioural factors is homogenous on all individuals or whether the demographic and psychographic characteristics of the individuals in any way influence the behavioural investment decision.

This research takes up one demographic variable, gender, and attempts to investigate the extent to which gender differences influence behavioural investment decisions. 


\section{Literature Review}

After many decades of supremacy, the assumption of human rationality was challenged by a new generation of researchers headed by Daniel Kahneman and Amos Tversky, who in their first research publication on the subject in 1974 discussed "Judgement under Uncertainty : Heuristics and Biases". Further in 1979, Kahneman and Tversky brought to public attention their new "Prospect Theory" in the journal Econometrica, which further challenged the rationality argument and entirely changed the way in which investment decision making was looked upon. Prospect Theory discovered behaviour patterns that had never been recognized by the proponents of rational decision making. One of the most striking and useful findings in the Prospect Theory of the Israeli psychologist duo Kahneman and Tversky was the asymmetry between the way humans make decisions involving gains and decisions involving losses. Kahneman and Tversky proposed and proved through multiple experiments that the same individual who is a risk averter for a decision involving gains becomes a risk seeker for a loss-avoiding decision.

Spurred by the path breaking Prospect Theory, a series of researches were successfully conducted by a group of academic economists led by Richard Thaler, David Bell, Meir Statman, Hersh Shefrin, Robert Shiller, et al resulting into a new field of study known as Behavioural Finance. Peter Bernstein, the founder editor of The Journal of Portfolio Management, in his incredible landmark book "Against the Gods - The Remarkable Story of Risk", published in 1996 writes -

"Behavioural Finance analyses how investors struggle to find their way through the give and take between risk and return, one moment engaging in cool calculation and the next yielding to emotional impulses. The result of this mixture between the rational and not-so-rational is a capital market that itself fails to perform consistently in the way theoretical models predict that it will perform"

The proponents of Behavioural Finance have stacked up many interesting experimentally verified theories to prove the quasi-rational behaviour of humans. According to Richard Thaler (1985), "quasi-rationality is neither fatal nor immediately self-defeating". Meir Statman and Hersh Shefrin, both Professors at the University of Santa Clara, in an illuminating paper on behavioural finance titled "Explaining Investor Preference for Cash Dividends" published in the Journal of Financial Economics, in 1984, first discussed another behavioural phenomenon known as 'mental accounting'. Statman and Shefrin hypothesized the existence of a split in the human psyche, one with a long term perspective, and the other favouring immediate gratification.

Richard Thaler and Werner DeBondt in their notable research work "Does the Stock Market Overreact?" presented at the Annual Meeting of American Finance Association in December 1985 demonstrated that investors do not objectively weigh new information but rather overweigh new and under-weigh prior and longer term information and hence over react.

In a 1992 paper that summarizes "Advances in Prospect Theory", Kahneman and Tversky made the observation that theories of choice are at best approximate and incomplete and that when faced with complex problems, people use computational shortcuts and editing operations. 
Another noteworthy research work "Contrarian Investment, Extrapolation and Risk" by three academicians Josef Lakonishok, Andre Shleifer and Robert Vishny, published in the National Bureau of Economic Research in May 1993, elaborated statistical which confirmed the hypothesis that "value" stocks tend to outperform more highly valued stocks. The three authors became so convinced by contrarian investment and other behavioural finance phenomenon that they launched their own firm LSV Asset Management in 1995 to manage money in accordance with their contrarian model.

In a 1995 paper on "Aspects of Investor Psychology", Kahneman and Mark W Riepe bring forth the beliefs, preferences and biases that humans have which influence their investment decision making. The authors put forward a series of well-researched recommendations for investment advisors to deal with such behavioural issues.

In June 2000, Meir Statman and Hersh Shefrin published a breakthrough research paper entitled "Behavioural Portfolio Theory" in which they have proposed a new model of portfolio selection as a parallel to the widely used Capital Asset Pricing Model. They have constructed a BPT Efficient Frontier and compared it with the mean-variance efficient frontier and concluded that in general, the two do not overlap. According to them, optimal BPT portfolios and optimal CAPM portfolios are also different from each other.

The evidence from various researches, experimental and otherwise, reveals repeated patterns of irrationality, inconsistency and incompetence in the way human beings arrive at decisions and choices when faced with uncertainty. (Peter Bernstein, 1996)

From the psychology perspective, a review of research reveals that Investor Psychology is a relatively very new development in the ancient science of psychology. However, being application based, it has attracted considerable attention from psychologists and finance (investment) professionals alike. The research in investor behaviour can be said to be broadly of two kinds, one that involves individual investors and hence a study of individual psychology and the other a study of group psychology or a study of the market and its movements as a whole.

On the basis of a questionnaire based study of 140 small investors and 175 professional investors/traders, Ira Epstein, a stockbroker and David Garfield, a psychologist, published a book in 1992, entitled "The Psychology of Smart Investing". In this book they presented the analysis of their survey, in which they identified six clusters or 'types' of investors which they named as overly cautious/paranoid investors, conflicted investors, masked investors, revenging/consumed investors, fussy investors and depressed investors. Interestingly, these investor 'types' closely resemble the mental disorder categories described by American Psychiatric Association. (Bernstein, 1996)

In a 2005 research paper, published in The Journal of Behavioural Finance, entitled "Risk Aversion and Personality Types", Greg Filbeck, Patricia Hatfield and Philip Horvath have explored the relationship between the personality type dimensions of the Myers Briggs Type Indicator (MBTI) and the moments approach to individual investor risk tolerance, inherent in expected utility theory.

In the words of Jonathan Myers, author of "Profits Without Panics: Investment Psychology for Personal Wealth" and founder of investment website psychonomics.com, "the way to improved financial returns is to match investments with investor's personality 
and needs". Myers has classified investors into cautious, emotional, technical, busy, casual and informed categories. He has also constructed various questionnaires and tools to determine the investor's personality.

One interesting study by Myers and many other financial analysts / researchers is about the role of gender in investment decision making. Are men and women different when it comes to financial decisions? The answer, as found out by many researchers is a resounding affirmative. Myers found that while men tend to be focused on results, goal directed and single minded with higher risk tolerance levels as well as high overconfidence levels, women, on the other hand, are multi-focussed, process driven, less tolerant of risk and less prone to over confidence.

Brad Barber and Terrance Odean in their 2001 research paper in the Quarterly Journal of Economics, entitled "Boys will be Boys : Gender, Overconfidence and Common Stock Investment" have also concluded similar results about gender specific financial behaviours. In a 2007 paper in Decision, the journal of IIM, Calcutta, entitled "Investment Decision Making : An exploration of the Role of Gender", Yesh Pal Davar and Suveera Gill have concluded after an intensive statistical enquiry that females have lower levels of awareness, lower confidence levels and lower risk tolerance capacities and hence are more cautious vis-à-vis males with regard to prospective investment in equity (risky) securities, especially if fund availability is low.

Jordan E Goodman in his book "Master Your Money Type" published in 2007 by Warner Business Books argues that there is a profound correlation between how an individual 'feels' about money and his financial decision. Goodman analyses the motivations that define an investor's attitude towards money and classifies investments into money types, each having common personality traits. Goodman recommends identification of one's money type as the first step towards investment decision making.

\section{Conceptual Framework of Behavioural Finance}

Behavioral finance is a field of study that seeks to combine behavioral and cognitive psychological theory with conventional economics and finance to provide explanations for why people make irrational financial decisions. The key concepts of behavioural finance are:

1. Anchoring: The concept of anchoring draws on the tendency to attach or "anchor" our thoughts to a reference point - even though it may have no logical relevance to the decision at hand.

2. Mental Accounting: Mental Accounting refers to the tendency for people to separate their money into separate accounts based on a variety of subjective criteria, like the source of the money and intent for each account.

3. Confirmation Bias: In investing, the confirmation bias suggests that an investor would be more likely to look for information that supports his or her original idea about an investment rather than seek out information that contradicts it.

4. Hindsight Bias: Another common perception bias is hindsight bias, which tends to occur in situations where a person believes (after the fact) that the 
onset of some past event was predictable and completely obvious, whereas in fact, the event could not have been reasonably predicted.

5. Gambler's Fallacy: In the gambler's fallacy, an individual erroneously believes that the onset of a certain random event is less likely to happen following an event or a series of events. This line of thinking is incorrect because past events do not change the probability that certain events will occur in the future.

6. Herd Behaviour: Refers to the tendency of individuals to mimic the actions (rational or irrational) of a larger group. Individually, however, most people would not necessarily make the same choice.

7. Over confidence: Refers to the tendency to overestimate or exaggerate one's ability to successfully perform a particular task. Investors often fall prey to this tendency which harms their interests in the long run.

8. Over-reaction: One consequence of having emotion in the stock market is the overreaction towards new information. According to market efficiency, new information should more or less be reflected instantly in a security's price. For example, good news should raise a business' share price accordingly, and that gain in share price should not decline if no new information has been released since. Reality, however, tends to contradict this theory. Oftentimes, participants in the stock market predictably overreact to new information, creating a larger-than-appropriate effect on a security's price.

9. Prospect Theory: Contends that people value gains and losses differently, and, as such, will base decisions on perceived gains rather than perceived losses. According to prospect theory, losses have more emotional impact than an equivalent amount of gains, so people are willing to take risks to avert losses while they become risk averse regarding prospective gains.

\section{Research Objective}

The objective of this research is to investigate whether gender plays a role in investment decision making and to find the extent to which men and women are influenced by behavioural finance phenomenon. The research also attempts to identify the points of difference between the two genders with respect to their vulnerability towards various behavioural phenomena.

\section{Research Methodology}

The research study has employed both secondary and primary data. The primary data was collected from salaried investors (the respondents) with the help of a structured questionnaire. The study employed non-probabilistic sampling method, with a judicious 
mix of convenience and judgmental sampling. The final sample size was 161, with representation from a wide cross-section. Chi-square test has been used for statistical analysis. The sample was collected during December 2008, from the city of Lucknow, India. The demographic profile of the respondents is elucidated in Table 1.

Table 1: Demographic Profile of Respondents

\begin{tabular}{|c|c|c|c|c|}
\hline & & $\begin{array}{c}\text { Females (\%) } \\
n=56\end{array}$ & $\begin{array}{c}\text { Males (\%) } \\
\mathbf{n}=105\end{array}$ & TOTAL \\
\hline \multirow[t]{5}{*}{ Age } & $\begin{array}{l}\text { Less than } 25 \\
\text { years }\end{array}$ & $9(16.07)$ & $13(12.38)$ & 22 \\
\hline & $26-35$ years & $21(37.50)$ & $48(45.72)$ & 69 \\
\hline & $36-45$ years & $16(28.57)$ & $24(22.86)$ & 40 \\
\hline & $>45$ years & $10(17.86)$ & $20(19.04)$ & 30 \\
\hline & TOTAL & $56(100.0)$ & $105(100.0)$ & 161 \\
\hline \multirow{4}{*}{$\begin{array}{l}\text { Educational } \\
\text { Qualifications }\end{array}$} & Graduate & $08(14.29)$ & $10(09.52)$ & 18 \\
\hline & $\begin{array}{l}\text { Post Graduate / } \\
\text { Professional }\end{array}$ & $45(80.36)$ & $92(87.62)$ & 137 \\
\hline & Doctorate & $03(05.35)$ & $03(02.86)$ & 06 \\
\hline & TOTAL & $56(100.0)$ & $105(100.0)$ & 161 \\
\hline \multirow[t]{3}{*}{ Employment } & $\begin{array}{l}\text { Govt. / Public } \\
\text { Sector }\end{array}$ & $20(35.71)$ & $22(20.95)$ & 42 \\
\hline & Private Sector & $36(64.29)$ & $83(79.05)$ & 119 \\
\hline & TOTAL & $56(100.0)$ & $105(100.0)$ & 161 \\
\hline \multirow[t]{4}{*}{$\begin{array}{l}\text { Annual } \\
\text { Income }\end{array}$} & $\begin{array}{l}\text { Less than } 1.8 \\
\text { lakhs }\end{array}$ & $19(33.92)$ & $17(16.19)$ & 36 \\
\hline & $1.8-3.6$ lakhs & $29(51.79)$ & $75(71.43)$ & 104 \\
\hline & $\begin{array}{l}\text { More than } 3.6 \\
\text { lakhs }\end{array}$ & $08(14.29)$ & $13(12.38)$ & 21 \\
\hline & TOTAL & $56(100.0)$ & $105(100.0)$ & 161 \\
\hline
\end{tabular}

\section{Hypothesis}

The following null hypotheses were formulated to study whether gender difference has any significant impact on investment behaviour and vulnerability to behavioural finance phenomenon.

$\mathbf{H}_{\mathbf{0 . 1}}$ There is no significant difference between male and female investors with regard to clarity of financial goals. 
$\mathbf{H}_{\text {0.2: }}$ There is no significant difference between male and female investors with regard to primary investment objective.

$\mathbf{H}_{\mathbf{0 . 3}}$ : There is no significant difference between male and female investors with regard to risk appetite.

$\mathbf{H}_{\mathbf{0 . 4}}$ : There is no significant difference between male and female investors with regard to susceptibility to mental accounting.

$\mathbf{H}_{\mathbf{0 . 5}}$ : There is no significant difference between male and female investors with regard to susceptibility to prospect theory.

$\mathbf{H}_{\mathbf{0 . 6}}$ : There is no significant difference between male and female investors with regard to tendency to over react to new market information.

$\mathbf{H}_{\text {0.7: }}$ There is no significant difference between male and female investors with regard to investor over-confidence.

$\mathbf{H}_{\mathbf{0 . 8}}$ : There is no significant difference between male and female investors with regard to susceptibility to herd behaviour.

\section{Analysis of Data \& Interpretation}

1.\# Gender and Clarity of Financial Goals: Clarity of financial goal signifies a situation wherein the investor has a very clear mental picture of where he is right now, where he wants to reach and how he will reach his destination. An exact investment target in terms of quantity as well as time horizon, alongwith a feasible and realistic plan to achieve the same would qualify as a precise financial goal.

The responses of male and female respondents with regard to clarity of financial goals have been tabulated in the following contingency table. (Table 2)

Table 2: Contingency Table of Gender with Clarity of Financial Goals

\begin{tabular}{|c|c|c|c|c|}
\hline $\begin{array}{c}\text { Clarity of } \\
\text { Goals }\end{array}$ & Male & Female & TOTAL & Percentage \\
\hline $\begin{array}{c}\text { Precise } \\
\text { Financial Goals }\end{array}$ & $21(18.26)$ & $07(9.74)$ & $\mathbf{2 8}$ & $\mathbf{1 7 . 3 9}$ \\
\hline $\begin{array}{c}\text { Somewhat } \\
\text { precise }\end{array}$ & $53(53.48)$ & $29(28.52)$ & $\mathbf{8 2}$ & $\mathbf{5 0 . 9 3}$ \\
\hline $\begin{array}{c}\text { Not precise at } \\
\text { all }\end{array}$ & $31(33.26)$ & $20(17.74)$ & $\mathbf{5 1}$ & $\mathbf{3 1 . 6 8}$ \\
\hline & $\mathbf{1 0 5}$ & $\mathbf{5 6}$ & $\mathbf{1 6 1}$ & $\mathbf{1 0 0}$ \\
\hline
\end{tabular}

$\mathbf{H}_{\mathbf{0 . 1}}$ : There is no significant difference between male and female investors with regard to clarity of financial goals.

Degree of Freedom: $(3-1)(2-1)=02$

Level of Significance: $95 \%$ 
Calculated Value of $\chi^{2}=1.6359$

Tabulated Value of $\chi^{2}=5.99$

As Calculated Value of $\chi^{2}$ is less than Tabulated Value, the Null Hypothesis $\left(\mathbf{H}_{0.1}\right)$ is Accepted at $95 \%$ level of significance, which means that there is no significant statistical difference between male and female investors with regard to clarity of financial goals.

As there is no difference between genders, the entire sample can be considered as homogenous, with regard to this attribute. The researchers found that only $17.39 \%$ of the total respondents had clear financial goals, $50.93 \%$ were somewhat clear while the remaining $31.68 \%$ frankly admitted to having no clarity in their financial goals.

2.\# Gender and Primary Investment Objective: There are only two primary objectives of investment, either current income or future capital appreciation, commonly called growth. Though an investor may give equal importance to both objectives, usually either income or growth is the primary objective while making investment decisions.

The responses of male and female respondents with regard to primary investment objective have been tabulated in the following contingency table. (Table 3 )

Table 3: Contingency Table of Gender with Primary Investment Objective

\begin{tabular}{|c|c|c|c|}
\hline Primary Investment Objective & Male & Female & TOTAL \\
\hline Growth & $64(48.91)$ & $11(26.09)$ & $\mathbf{7 5}$ \\
\hline Income & $23(27.39)$ & $19(14.61)$ & $\mathbf{4 2}$ \\
\hline Both & $18(28.70)$ & $26(15.30)$ & $\mathbf{4 4}$ \\
\hline & $\mathbf{1 0 5}$ & $\mathbf{5 6}$ & $\mathbf{1 6 1}$ \\
\hline
\end{tabular}

$\mathbf{H}_{\mathbf{0 . 2}}$ : There is no significant difference between male and female investors with regard to primary investment objective.

Degree of Freedom: $(3-1)(2-1)=02$

Level of Significance: $95 \%$

Calculated Value of $\chi^{2}=26.878$

Tabulated Value of $\chi^{2}=5.99$

As Calculated Value of $\chi^{2}$ is more than Tabulated Value, the Null Hypothesis $\left(\mathbf{H}_{0.2}\right)$ is Rejected at $95 \%$ level of significance, which means that there is a significant statistical difference between male and female investors with regard to primary investment objective.

An analysis of the contingency table clearly reveals that while male investors are more prone towards growth objective, female investors are more inclined towards either income or both income and growth objectives. 
3.\# Gender and Risk Appetite: Risk appetite means whether the investor is ready to bear high risk for getting high returns. How much fluctuation can the investor bear in his investments without losing a night's sleep or without making a panic exit? The answer to this question determines the risk appetite. The investor who can stomach the highest risk is called Aggressive, while the one who cannot tolerate any risk is called Conservative.

The responses of male and female respondents with regard to risk appetite have been tabulated in the following contingency table. (Table 4)

Table 4: Contingency Table of Gender with Risk Appetite

\begin{tabular}{|c|c|c|c|}
\hline Risk Appetite & Male & Female & TOTAL \\
\hline Aggressive & $48(43.04)$ & $18(22.96)$ & $\mathbf{6 6}$ \\
\hline Moderate & $37(35.22)$ & $17(18.78)$ & $\mathbf{5 4}$ \\
\hline Conservative & $20(26.74)$ & $21(14.26)$ & $\mathbf{4 1}$ \\
\hline & $\mathbf{1 0 5}$ & $\mathbf{5 6}$ & $\mathbf{1 6 1}$ \\
\hline
\end{tabular}

$\mathbf{H}_{\mathbf{0 . 3}}$ : There is no significant difference between male and female investors with regard to risk appetite.

Degree of Freedom: $(3-1)(2-1)=02$

Level of Significance: $95 \%$

Calculated Value of $\chi^{2}=6.7866$

Tabulated Value of $\chi^{2}=5.99$

As Calculated Value of $\chi^{2}$ is more than Tabulated Value, the Null Hypothesis $\left(\mathbf{H}_{0.3}\right)$ is Rejected at $95 \%$ level of significance, which means that there is a significant statistical difference between male and female investors with regard to risk appetite.

An analysis of the contingency table clearly reveals that male investors are more risk aggressive, while female investors are more conservative.

4.\# Gender and Susceptibility to Mental Accounting: Mental Accounting refers to the tendency for people to separate their money into separate accounts based on a variety of subjective criteria, like the source of the money and intent for each account. For example, people would be willing to go on a luxury cruise using lottery money but not with salary money. Due to the same faulty logic, the investors might be saving money in one account to buy some specified item, while at the same time drowning on credit card debt.

The responses of male and female respondents with regard to susceptibility to mental accounting have been tabulated in the following contingency table. (Table 5)

Table 5: Contingency Table of Gender with Susceptibility to Mental Accounting

\begin{tabular}{|c|c|c|c|c|}
\hline $\begin{array}{c}\text { Susceptibility to } \\
\text { Mental }\end{array}$ & Male & Female & TOTAL & Percentage \\
\hline
\end{tabular}




\begin{tabular}{|c|c|c|c|c|}
\hline Accounting & & & & \\
\hline Susceptible & $74(73.04)$ & $38(38.96)$ & $\mathbf{1 1 2}$ & $\mathbf{6 9 . 6}$ \\
\hline Not Susceptible & $31(31.96)$ & $18(17.04)$ & $\mathbf{4 9}$ & $\mathbf{3 0 . 4}$ \\
\hline & $\mathbf{1 0 5}$ & $\mathbf{5 6}$ & $\mathbf{1 6 1}$ & $\mathbf{1 0 0}$ \\
\hline
\end{tabular}

$\mathbf{H}_{\mathbf{0 . 4}}$ : There is no significant difference between male and female investors with regard to susceptibility to mental accounting.

Degree of Freedom: $(2-1)(2-1)=01$

Level of Significance: $95 \%$

Calculated Value of $\chi^{2}=0.1192$

Tabulated Value of $\chi^{2}=3.84$

As Calculated Value of $\chi^{2}$ is less than Tabulated Value, the Null Hypothesis $\left(\mathbf{H}_{0.4}\right)$ is Accepted at $95 \%$ level of significance, which means that there is no significant statistical difference between male and female investors with regard to susceptibility to mental accounting.

As there is no difference between genders, the entire sample can be considered as homogenous, with regard to this attribute. So it can be said that $69.6 \%$ of the sample is susceptible to mental accounting, while $30.4 \%$ are not susceptible.

5.\# Gender and Susceptibility to Prospect Theory: Prospect Theory contends that people value gains and losses differently and losses have more emotional impact than an equivalent amount of gains, so people are willing to take more risks to avert losses while they become risk averse with regard to prospective gains.

The responses of male and female respondents with regard to susceptibility to Prospect Theory have been tabulated in the following contingency table. (Table 6)

Table 6: Contingency Table of Gender with Susceptibility to Prospect Theory

\begin{tabular}{|c|c|c|c|}
\hline $\begin{array}{c}\text { Susceptibility to Prospect } \\
\text { Theory }\end{array}$ & Male & Female & TOTAL \\
\hline Susceptible & $82(75)$ & $33(40)$ & $\mathbf{1 1 5}$ \\
\hline Not Susceptible & $23(30)$ & $23(16)$ & $\mathbf{4 6}$ \\
\hline & $\mathbf{1 0 5}$ & $\mathbf{5 6}$ & $\mathbf{1 6 1}$ \\
\hline
\end{tabular}

$\mathbf{H}_{\mathbf{0 . 5}}$ : There is no significant difference between male and female investors with regard to susceptibility to prospect theory.

Degree of Freedom: $(2-1)(2-1)=01$

Level of Significance: 95\%

Calculated Value of $\chi^{2}=6.5743$

Tabulated Value of $\chi^{2}=3.84$ 
As Calculated Value of $\chi^{2}$ is more than Tabulated Value, the Null Hypothesis $\left(\mathbf{H}_{0.5}\right)$ is Rejected at $95 \%$ level of significance, which means that there is a significant statistical difference between male and female investors with regard to susceptibility to Prospect Theory.

A deeper analysis of the contingency table clearly reveals that male investors are more susceptible to Prospect theory than are female investors.

6.\# Gender and Tendency to Over-react in response to new market information: Participants in financial markets often overreact to new information, creating a larger-than-appropriate effect on a security's price, that is, positive information is followed by an unjustified steep rise in price while negative information is followed by unjustified steep decline in prices. At other times, simply market sentiment may cause prices to steeply rise or fall without any fundamental justification.

The responses of male and female respondents with regard to tendency to over react have been tabulated in the following contingency table. (Table 7)

Table 7: Contingency Table of Gender with Tendency to Over-react

\begin{tabular}{|c|c|c|c|}
\hline Over-reaction & Male & Female & TOTAL \\
\hline Yes & $79(72.39)$ & $32(38.61)$ & $\mathbf{1 1 1}$ \\
\hline No & $26(32.61)$ & $24(17.39)$ & $\mathbf{5 0}$ \\
\hline & $\mathbf{1 0 5}$ & $\mathbf{5 6}$ & $\mathbf{1 6 1}$ \\
\hline
\end{tabular}

$\mathbf{H}_{\mathbf{0 . 6}}$ : There is no significant difference between male and female investors with regard to tendency to over react to new market information.

Degree of Freedom: $(2-1)(2-1)=01$

Level of Significance: $95 \%$

Calculated Value of $\chi^{2}=5.5865$

Tabulated Value of $\chi^{2}=3.84$

As Calculated Value of $\chi^{2}$ is more than Tabulated Value, the Null Hypothesis $\left(\mathbf{H}_{\mathbf{0 . 6}}\right)$ is Rejected at 95\% level of significance, which means that there is a significant statistical difference between male and female investors with regard to tendency to over react to financial market information.

An analysis of the contingency table clearly reveals that male investors tend to over react more than their female counterparts.

7.\# Gender and Investor Over-confidence: Self Confidence refers to one's own estimation of one's ability to successfully perform a particular task. There is a very thin line of difference between self confidence and overconfidence. While self confidence is a positive attribute, if overdone it results in extremely 
negative consequences. In the investment world, over confidence amounts to self destruction.

The responses of male and female respondents with regard to tendency to over react have been tabulated in the following contingency table. (Table 8)

Table 8: Contingency Table of Gender with Investor Over-Confidence

\begin{tabular}{|c|c|c|c|}
\hline $\begin{array}{c}\text { Investor Over- } \\
\text { confidence }\end{array}$ & Male & Female & TOTAL \\
\hline Above Average & $29(22.83)$ & $06(12.17)$ & $\mathbf{3 5}$ \\
\hline Average & $60(61.30)$ & $34(32.70)$ & $\mathbf{9 4}$ \\
\hline Below Average & $16(20.87)$ & $16(11.13)$ & $\mathbf{3 2}$ \\
\hline & $\mathbf{1 0 5}$ & $\mathbf{5 6}$ & $\mathbf{1 6 1}$ \\
\hline
\end{tabular}

$\mathbf{H}_{\text {0.7: }}$ There is no significant difference between male and female investors with regard to investor over-confidence.

Degree of Freedom: $(3-1)(2-1)=02$

Level of Significance: $95 \%$

Calculated Value of $\chi^{2}=8.1427$

Tabulated Value of $\chi^{2}=5.99$

As Calculated Value of $\chi^{2}$ is more than Tabulated Value, the Null Hypothesis $\left(\mathbf{H}_{0.7}\right)$ is Rejected at 95\% level of significance, which means that there is a significant statistical difference between male and female investors with regard to investor over-confidence.

An analysis of the contingency table clearly reveals that male investors tend to be more over-confident as compared to their female counterparts

8.\# Gender and Susceptibility to Herd Behaviour: Herd behaviour implies the extent to which individuals are influenced by what the majority of the people are doing. Going with the herd seems safe and self fulfilling. The interesting thing about herd behaviour is that the same individuals, if they were making independent individual decisions, would not have made the same choice.

The responses of male and female respondents with regard to susceptibility to herd behaviour have been tabulated in the following contingency table. (Table 9)

Table 9: Contingency Table of Gender with Susceptibility to Herd Behaviour

\begin{tabular}{|c|c|c|c|c|}
\hline $\begin{array}{c}\text { Susceptibility to } \\
\text { Herd Behaviour }\end{array}$ & Male & Female & TOTAL & Percentage \\
\hline $\begin{array}{c}\text { Susceptible to a } \\
\text { Large Extent }\end{array}$ & $27(29.35)$ & $18(15.65)$ & $\mathbf{4 5}$ & $\mathbf{2 7 . 9}$ \\
\hline $\begin{array}{c}\text { Susceptible to a } \\
\text { Small Extent }\end{array}$ & $56(56.74)$ & $31(30.26)$ & $\mathbf{8 7}$ & $\mathbf{5 4 . 0}$ \\
\hline
\end{tabular}




\begin{tabular}{|c|c|c|c|c|}
\hline Not Susceptible & $22(18.91)$ & $07(10.09)$ & $\mathbf{2 9}$ & $\mathbf{1 8 . 1}$ \\
\hline & $\mathbf{1 0 5}$ & $\mathbf{5 6}$ & $\mathbf{1 6 1}$ & $\mathbf{1 0 0}$ \\
\hline
\end{tabular}

$\mathbf{H}_{\mathbf{0 . 8}}$ : There is no significant difference between male and female investors with regard to susceptibility to herd behaviour

Degree of Freedom: $(3-1)(2-1)=02$

Level of Significance: 95\%

Calculated Value of $\chi^{2}=2.0202$

Tabulated Value of $\chi^{2}=5.99$

As Calculated Value of $\chi^{2}$ is less than Tabulated Value, the Null Hypothesis is Accepted at 95\% level of significance, which means that there is no significant statistical difference between male and female investors with regard to susceptibility to herd behaviour.

As there is no difference between genders, the entire sample can be considered as homogenous, with regard to this attribute. So it can be said that $27.9 \%$ of the sample is susceptible to herd behaviour to a large extent and $54 \%$ to a small extent, while $18.1 \%$ are not susceptible and prefer making independent decisions.

\section{Conclusion and Recommendations}

A thorough analysis of the data collected through structured interviews shows with total clarity and no degree of doubt that investors are not playing the investment game scientifically. There is a high degree of behavioural influence in their investment decisions which may lead to sub-optimum results, scientifically speaking. However, it is interesting to note that investors are largely satisfied with the way things are. This seems to suggest that investors are not machines, and that they are content with their own un-scientific fuzzy logic and emotional decisions, even though many of them are aware of their suboptimum investment performance.

However, the influence of behavioural factors on men and women shows a considerable variation. It may sound a reiteration of an age old belief, but this research has once again proved that men and women are not alike. In only three amongst the eight attributes tested do men and women seem similar, that is they are both largely clueless about the clarity of their financial goals, and both are equally susceptible to behavioural fallacies such as mental accounting and herd behaviour.

However, amongst the remaining five attributes, there are significant differences in the way men and women behave. While women are more conservative in their risk-taking behaviours, they are also less prone to over confidence and overreaction and in general do not subscribe to the prospect theory. Women are also more likely to invest for income objective rather than growth.

Men, on the other hand, are more aggressive financial decision makers and aim for growth objective rather than income. However, they are also more prone to behavioural 
aberrations like over-confidence and over-reaction and also extensively subscribe to the prospect theory.

What is the implication of this research for the financial industry? The implication is that the population as a whole is behaviourally inclined and unless they see emotion in reason, rather than the opposite, they would not feel comfortable or content. Also, significant variations in the financial behaviours of men and women would entail construction of customized portfolios for each with regard to their individual preferences and eccentricities. The financial services industry, especially investment advisors, should wake up to this call and make gender-specific behavioural adjustments to their portfolio advice.

An apt way to do this would be the creation and use of psychometric testing devices for investors to measure their demographic and psychographic characteristics. Thereafter, customized behavioural portfolios can be constructed so as to maximize the financial as well as psychological well being of the investors.

\section{References}

Analyzing \& Aiding Decision Processes, Edited by P Humphreys, O Svenson \& A Vari, Pg $525-543$.

Barber Brad and Odean Terrance., Boys will be Boys : Gender, Overconfidence and Common Stock Investment, The Quarterly Journal of Economics, February 2001.

Baron Robert A., Psychology, Pearson Education, Fifth Edition, 2008

Bernstein Peter L., Against the Gods - The Remarkable Story of Risk, John Wiley \& Sons Inc., 1996.

Davar Yesh Pal and Gill Suveera., Investment Decision Making : An Exploration of the Role of Gender, Decision, Volume 34, No 1, Jan-Jun 2007

Davis Stephen F and Smith Randolph A., An Introduction to Statistics \& Research Methods - Becoming a Psychological Detective, Pearson Education, 2005.

Epstein Ira and Garfield David., The Psychology of Smart Investing, 1992.

Feldman Robert S., Understanding Psychology, McGraw Hill Book Company, 1987.

Filbeck Greg, Hatfield Patricia and Horvath Philip., Risk Aversion and Personality Types, Journal of Behavioural Finance, 2005

Goodman Jordan E., Master your Money Type, Warner Business Books, 2007

Kahneman D and Riepe Mark W., Aspects of Investor Psychology, Journal of Portfolio Management, Volume 24, No. 4.

Kahneman D and Tversky Amos., Prospect Theory: An Analysis of Decision under Risk, Econometrica, Volume 47, No. 2, 1979, Page 263 - 291.

Myers Jonathan, Profits Without Panics: Investment Psychology for Personal Wealth, John Wiley \& Sons. 
https://ir.iba.edu.pk/businessreview/vol7/iss $2 / 2$

DOI: https://doi.org/10.5 Business Review - Volume 7 Number 2

July - December 2012

Schmitt David P et al., Why can't a Man be more like a Woman : Sex Differences in Big 5 Personality Traits Across 55 Cultures, Journal of Personality \& Social Psychology, Volume 94, No. 1, January 2008

Shefrin Hersh and Statman Meir., Behavioural Portfolio Theory, Journal of Financial And Quantitative Analysis, June 2000

Silva Fernandes., Psychometric Foundations \& Behavioural Assessment, Sage Publications, 1993.

Statman Meir, A Behavioural Framework for Dollar Cost Averaging, Journal of Portfolio Management, Volume 22, No. 1.

Tvede Lars., The Psychology of Finance - Understanding the Behavioural Dynamics of Markets, Wiley Trading, Revised Ed 2002.

Williams James O., Maximising the Probability of Achieving Investment Goals, Journal of Portfolio Management, Volume 24, No. 1.

"Religious distress is at the same time, the expression of real distress and a protest against real distress. Religion is the sigh of the oppressed creature, the heart of a heartless world, just as it is the spirit of a spiritless situation. It is the opium of the people."

Marx 